\title{
Using Inquiry-based Laboratory Activities in Lights and Optics Topic to Improve Students' Understanding about Nature of Science (NOS)
}

\author{
Tiara B Wardani, ${ }^{1,2 *}$, Nanang Winarno ${ }^{2}$ \\ ${ }^{1}$ Putra Pertiwi Kindergarten and learning courses, Indonesia \\ ${ }^{2}$ International Program on Science Education, Universitas Pendidikan Indonesia, Indonesia \\ *Corresponding Author. tiara.budi.wardani@student.upi.edu
}

\begin{abstract}
The aim of this study was to determine the effect of inquiry-based laboratory activities on the students' understanding of the nature of science (NOS) in learning lights and optics topic. The method used in this research is quasi experiment. Sampling technique using random sampling to class and the samples were taken from grade 8 in one of junior high school in Bandung. The sample was 45 students, consisting of the experimental class ( $\mathrm{n}=24$ students) and the control class ( $n=21$ students). The experimental class is taught by inquiry-based laboratory activities, while the control class is taught by noninquiry laboratory activities. The result of this research shows that the experimental class got N-Gain of 0.60 , while the control class got N-Gain of 0.44 , and both classes proven to have statistically significant different improvement.
\end{abstract}

Keywords Inquiry based Laboratory Activities, Nature of Science, Lights and Optics

\section{INTRODUCTION}

Indonesia National Curriculum of 2013 states that teaching learning process at school should guide the students to experience five learning aspects which are being emphasized in this curriculum, they are observing, questioning, experimenting, associating, and communicating (Brookes Publishing, 2012). Those five learning experiences which are the stages of Inquiry are used by the government to support Indonesia in reaching the education objectives. The mission and orientation of Indonesia National Curriculum of 2013 is translated in educational practice with the specific purpose so that learners or students have the necessary competences to the lives of society today and in the future. The competences are included: (1) foster religious attitude and high social ethics in the life of society, nation and state; (2) the acquisition of knowledge; (3) have the skills or the ability to apply knowledge in order to conduct scientific inquiry, problem solving, and the making of creative works related to everyday life (KementerianPendidikandanKebudayaan, 2015).

The ideal condition that government expected has not yet been reached. It can be seen from international comparative survey such as PISA (Program for International Student Assessment), the score of Indonesia in science is only 403, while the average score is 497
(OECD Data, 2015). and the students' skills in applying the knowledge in order to conduct scientific inquiry, problem solving, and the making of creative works related to everyday life is still also low. The poor performance of students attests to the fact that the teaching and learning have not been effective enough (Olubu, 2015). It depicts lack of acquisition of the required skills which may be as a result of inadequate exposure of learners to inquiry laboratory activities. This condition is an indication of a gap in the system of teaching and learning of science in Junior High School which require investigation and remediation (Olubu, 2015).

The above condition may occur because natural science subject is one of the subjects that has many difficulties for many students included for Junior High School students (BBC News, 2005). These difficulties then could lead students to have low motivation in learning science, although actually in this school level they should have a good concept understanding about natural science in order to be their foundation for learning natural science in the next school level. It is in line with what stated by Anderman

Received: 28 October 2017

Revised: 29 November 2017

Published: 30 November 2017

. 
and Sinatra (2008) that the state of science education for teenagers is at an important crossroad.

As one of the main part of science subject, light and optics topic is also considered as difficult topic. Light and optics is a rapidly developing and often encountered its technological practices in everyday lives (Tural, G., 2015). However teaching and learning the subject of lights and optics is challenging for teachers and students (Tural, G., 2015). Teaching the teenagers or adolescents will also emerge unique challenges for science educators, it is because in the adolescent phase students are facing the transition phase means that students are in the process of trying to understand the abstract concepts where in the previous school level or child phase they only learn the concrete one (Anderman and Sinatra, 2008).

To solve those problems, educators should provide a form of teaching and learning activity which can attract the interest of students (Tural, G., 2015). Teacher could facilitate students with learning activity which engage students to think deeply about the learning material in appropriate level. The conceptual mastery of the students can be enhanced when the students were provided with "learn-by-doing" or kinesthetic modes of knowledge acquisition (Olubu, 2015). Learning science including physics is not only the acquisition in the form of facts, concept, principles or theory but learning will be more meaningful if the students experience or observe it directly (Tural, G., 2015).

A focus on meaningful learning is consistent with the view of learning as knowledge construction, in which students seek to make sense of their experiences (Ausubel, 1969). Science is better to be taught using experimentation, it should be taught through activity-based approach in a well-equipped laboratory learning environment (Azer et al., 2013). Inquiry-based learning is one approach using more student-directed, interactive methods of learning and focusing on learning how to learn (Wolf and Fraser, 2007). The laboratory can help the teachers to demonstrate practically some of the principles taught in theory. However, based on a survey done by the researcher in 2016, it showed that in Indonesia there is still lack inquiry laboratory activity conducted to support the learning process. So, inquiry based laboratory activity is expected to have positive effects toward Junior High School students' conceptual mastery.

Previously, there are several researches already conducted to test the effectiveness of inquiry based laboratory method, such as a research conducted by Azer et al. (2013), this research investigating the students' conceptual mastery and attitude after treated with laboratory learning (Olubu, 2015). Also a research conducted by Bünning (2013) which evaluate empirically the effects of experimental learning on learning achievement (Bunning, 2013) and the research that conducted by Olubu (2015) also investigated the effects of laboratory learning environment on students' learning outcomes in secondary school Chemistry, almost all of them showed a positive effect. Such research could further suggest changes to educational standards and practices (Olubu, 2015). If inquiry-based learning can improve student outcomes in physical science, then similar strategies could work in other subject areas and for other age groups. This research was initiated to evaluate the effectiveness of using inquiry-based laboratory activities among 8th Grade students in terms of students' understanding about Nature of Science (NOS) in lights and optics topic. As well, this research also examined the differential effectiveness of inquiry activities for male and female students.

\section{METHOD}

The research method used in this research is Quasi Experiment. Quasi experiment includes assignment, but not random assignment of participants to groups (Creswell, 2012). Creswell (2012) stated that it can be used when the researcher cannot artificially create groups for the experiment. This method is appropriate with the purpose of the research which is investigating the effect of inquiry laboratory activity by comparing the inquiry and noninquiry laboratory activity in terms of students' understanding about Nature of Science (NOS) among junior high school students in the topic of lights and optics. The design that will be used in this research is pre-test and post-test design. The researcher assigns intact groups of the experimental and control groups, administers a pre-test to both groups, conducts experimental treatment activities with the experimental group only, and then administers a post-test to assess the differences between the two groups (Creswell, 2012).

This research conducted in one of Junior High School in Bandung which implements the Indonesia National Curriculum of 2013. The participants of this research is 44 students from 8th grade. The samples are two classes in eighth grade, one of the classes will act as a control group,

Table 1 Pre-test and post-test design

\begin{tabular}{llll} 
Select Control & Pre-test & $\begin{array}{l}\text { Non-inquiry } \\
\text { based } \\
\text { laboratory } \\
\text { activity }\end{array}$ & Post-test \\
\hline $\begin{array}{l}\text { Select } \\
\text { Experimental } \\
\text { Class }\end{array}$ & Pre-test & $\begin{array}{l}\text { Inquiry based } \\
\text { laboratory } \\
\text { activity }\end{array}$ & Post-test \\
\hline
\end{tabular}

Table 2 The Percentage of Students' Gender

\begin{tabular}{llrll}
\hline \multirow{2}{*}{ Gender } & \multicolumn{2}{c}{ Experiment Class } & \multicolumn{2}{c}{ Control Class } \\
\cline { 2 - 5 } & $\begin{array}{c}\text { Number of } \\
\text { Students }\end{array}$ & $\begin{array}{c}\text { Percen } \\
\text { tage }\end{array}$ & $\begin{array}{c}\text { Number of } \\
\text { Students }\end{array}$ & $\begin{array}{c}\text { Percen } \\
\text { tage }\end{array}$ \\
\hline Male & 13 & $54,2 \%$ & 12 & $57,1 \%$ \\
Female & 11 & $45,8 \%$ & 9 & $42.9 \%$ \\
Total & 24 & $100 \%$ & 21 & $100 \%$ \\
\hline
\end{tabular}


Table 3 The recapitulation of statistical test result of nature of science (NOS)

\begin{tabular}{|c|c|c|c|c|}
\hline \multirow{2}{*}{ Component } & \multicolumn{2}{|l|}{ Pretest } & \multicolumn{2}{|l|}{ Posttest } \\
\hline & Experiment Class & Control Class & Experiment Class & Control Class \\
\hline $\mathbf{N}$ & 24 & 21 & 24 & 21 \\
\hline Average Score & $-15,71$ & $-15,95$ & 22,17 & 12,76 \\
\hline $\begin{array}{l}\text { Standard } \\
\text { Deviation }\end{array}$ & 11,63 & 9,79 & 9,49 & 6,83 \\
\hline Maximum Score & 9 & 10 & 45 & 32 \\
\hline $\begin{array}{l}\text { Minimum Score } \\
\text { Normality Test }\end{array}$ & -33 & -32 & 2 & 3 \\
\hline $\begin{array}{l}\text { Signification } \\
(\operatorname{sig} \alpha=0,05)\end{array}$ & 0,639 & 0,551 & 0,526 & 0,480 \\
\hline Information & Normally distributed & $\begin{array}{l}\text { Normally } \\
\text { distributed }\end{array}$ & Normally distributed & $\begin{array}{l}\text { Normally } \\
\text { distributed }\end{array}$ \\
\hline $\begin{array}{l}\text { Homogeneity Te } \\
\text { Signification } \\
(\operatorname{sig} \alpha=0,05)\end{array}$ & \multicolumn{2}{|l|}{0,325} & \multicolumn{2}{|l|}{0,232} \\
\hline $\begin{array}{l}\text { Information } \\
\text { Hypothesis Test }\end{array}$ & \multicolumn{2}{|c|}{ Both data are homogeny. } & \multicolumn{2}{|l|}{ Both data are homogeny. } \\
\hline \multirow{2}{*}{$\begin{array}{l}\text { Signification } \\
(\operatorname{sig} \alpha=0,05)\end{array}$} & \multicolumn{2}{|c|}{ Independent Sample T-Test } & \multicolumn{2}{|l|}{ Independent Sample T-Test } \\
\hline & \multicolumn{2}{|l|}{0,940} & \multicolumn{2}{|l|}{0,001} \\
\hline $\begin{array}{l}\text { Information } \\
\text { Conclusion }\end{array}$ & \multicolumn{2}{|l|}{$\mathrm{H}_{0}$ is accepted } & \multicolumn{2}{|l|}{$\mathrm{H}_{0}$ is rejected } \\
\hline
\end{tabular}

while the other one will be as experimental group. There are 22 students in each groups, the experimental group consist of 10 females and 12 males while the control group consist of 13 females and 9 males. Their ages ranged between 14 to 16 years old.

The sampling technique that used in this research was simple random sampling to class. In this research, one class was randomly chosen as experimental class while the other as the control class (Fraenkel, J. R., 2007). Then, after the random lottery has been conducted, one class consisted of 24 students was taken as experimental class, while the other class consisted of 21 students taken as control class. Both group generally consisted of almost half males and half females with the age around 14 years old.

\section{RESULT AND DISCUSSION}

\subsection{The Effect of Inquiry based Laboratory Activity on Students' Understandingabout Nature of Science (NOS)}

Students' understanding about Nature of Science (NOS) was measured using SUSSI (Student Understanding of Science and Scientific Inquiry) questionnaire which was developed by Liang et al. (2008) SUSSI was a questionnaire in form of Likert-type items to assess students' understandings on the nature of science (NOS) in terms of six aspects which are observations and inferences, tentativeness, scientific theories and laws, social and cultural embeddedness, creativity and imagination, and scientific methods.
SUSSI questionnaire allows the use of inferential statistics to determine the effect of any instructional interventions in small or large scale study. Therefore, the statistical test was done in order to calculate the difference of students' understanding about Nature of Science (NOS) between the experimental and control class. The table below is the recapitulation of statistical test result of the experiment class and control class.

SUSSI questionnaire can be used flexibly and the result can be processed statistically (Liang et al., 2008). Then this research employed the SPSS to test the hypothesis. But before it, the normality and homogeneity of the data have to be calculated in order to decide which statistic method was appropriate, whether parametric or non-parametric.

The normality test result of pretest and posttest from experiment and control groups shows that both data are normally distributed, because the result shows the values which are more than 0,05 . The same with normality test result, the homogeneity test result of pretest and posttest from both groups also shows a value which are more than 0,05 , so it can be said that the data is homogeny. Then, because the data were normal and homogeny, than it decided to compare the mean, it used parametric statistics which was Independent Sample T-Test.

The Table 3 shows that the sig. value of Independent Sample T-Test from pretest is less than 0,05. It means that the pretest score of both groups was statistically not significant different. It can be interpreted that the students' prior understanding about Nature of Science in both classes was not really different. The students from both classes have not read or taught about the theory of nature 


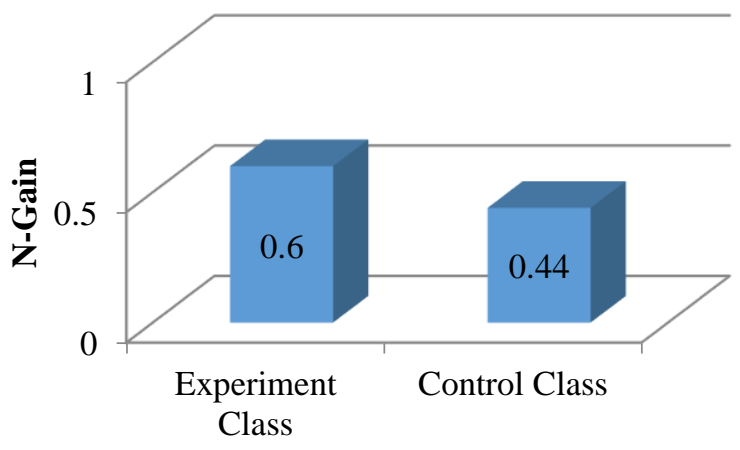

Class

Figure $1 \mathrm{~N}$-gain comparison of experiment and control class

of science, and that is why they got low score of pretest, which is around -15 , moreover the students have not familiar yet with the form of the test items.

Nevertheless, the average score of posttest of both classes were proven to be significantly different. It can be seen from the hypothesis test of posttest score. This could be happend because of the effect of the different treatments implemented to both groups. The experimental group which implemented Inquiry based Laboratory Activity got better score than the control one which implemented non Inquiry based Laboratory Activity. This result is in line with the result of previous research that this model can improve the understanding about Nature of Science (NOS) better than the control one (Ozgelen,Tuzun, and Hanuscin ,2012).

Inquiry-based laboratory activity improve students' understanding about Nature of Science better by involving students in scientific atmosphere where they were allowed to try how the scientist works. They are stimulated to pose scientifically oriented questions, collect and analyse data, form hypotheses, design and conduct scientific investigations, formulate and revise scientific explanations, and communicate arguments (Hofstein, A. and Lunneta V.N., 2004), and it is cohere with the scientific method.

In the control class with conventional laboratory settings, students are usually only follow step-by-step instructions to complete an experiment. Hofstein and Lunetta (2004) stated that the students generally only concentrate on the completion of individual steps but did not really concentrate to the knowledge behind the experiment itself so they often do not have a deep understanding of the scientific experiment design and did not open their views or understanding about Nature of Science (NOS) (Hofstein, A. and Lunneta V.N., 2004).

To see the clearer comparison between the improvement of students understanding about Nature of Science (NOS), the Normalized Gain (N-Gain) have to be calculated, the experiment class got N-Gain of 0,60 and it was categorized as high improvement based on Hake (1999). While the control class got 0,44 which categorized as medium improvement. The comparison of N-Gain from both classes is provided as the Figure 1.

This study shows that both learning with inquiry and non inquiry based laboratory activity, both can improve the view or understanding of the nature of science (NOS). The improvement of students' understanding about Nature of Science (NOS) in both classes is cohere with the mentioned literature review that laboratory activities have long had a distinctive and central role in science and educators have suggested that many benefits accrue from engaging students in science laboratory activities (Garnett and Hackling 2005; Hofstein, A. and Lunneta V.N., 2004;Hofstein et al. 2004; Lunetta 2008; Tobin 1998) and the America's Lab Report (2006) also stated that laboratory experience may enhance the students' understanding of specific scientific facts and concepts and of the way which these facts and concepts are organized in the scientific disciplines, it develops the scientific reasoning by promoting the students' ability in identifying the questions and concept.

The students' understanding about Nature of Science (NOS) is measured by using SUSSI questionnaire in a form of Likert-scale questionnaire. Those statements in the questionnaire represent the aspects of students' understanding about Nature of Science (NOS). As what has been explained before that in this research the aspects that involved were observations and inferences, tentativeness, scientific theories and laws, social and cultural embededdness, creativity and imagination, and scientific methods.

\subsection{The effect of inquiry based laboratory activity in every aspect of Nature of Science (NOS)}

The students' improvement of understanding about Nature of Science (NOS) are also supported by the result of statistical tests showing that the implementation of inquiry based laboratory activity can improve more students' understanding about Nature of Science (NOS) in every aspects compared to conventional laboratory activity. The improvement of students' understanding about Nature of Science (NOS) using inquiry based laboratory activity in general is evident from the increase in the average value of each aspects. Below is the table of the score of NOS in each aspect. Based on the SUSSI questionnaire by Liang et al. (2008) the maximum score that can be gained by the students in each aspect with 4 statements is 8 , while the minimum score is -8 .

According to the result of the research, the detail of students' achievement on six aspect of Nature of Science (NOS) can be described. The score of each aspects shows different result of students' acquisition either in pretest or posttest. In the pretest, from both classes generally the students obtained the high score in observation and inferences aspect. It is might be because the questions in this subtopic were the basic knowledge about science and 
they might have learned about it in previous grade or in the primary school. In addition, the lowest pretest score obtained by both classes is in the aspect of scientific theories and law. Many of the students think that scientific laws cannot be replaced by the new laws, since they only know several science laws. They have not known or taught about the laws which have been replaced.

\subsection{The categorization of students understanding about Nature of Science (NOS)}

Beside considering the effect between both treatments through the improvement chart, it also needs to categorize the students' views or understanding about Nature of Science (NOS) into three categories which are Informed, Intermediary and Naïve Views (Liang et al., 2008) and Khishfe and Laderman, 2006) in every aspects involved in the questionnaire (SUSSI questionnaire) which are observations and inferences, tentativeness, scientific theories and laws, social and cultural embededdness, creativity and imagination, and scientific methods.

The students' views were categorized as Naive Views if none of four responses received a score $>3$ within each theme; the students views were categorized as Intermediate Views if several responses received a score $>3$ within each theme; the students views were categorized as Informed Views if all four responses received a score $>3$ within each theme (Khishfe and Laderman, 2006, and Liang et al., 2008. The categorization result of students' views based on the views of the informed, and naive categories of the nature of science are presented in Table 5.

Developing students' informed views on the nature of science is one of the main goals in science education (Khishfe and Laderman, 2006). The increased percentage of informed views indicates an increase in students' view of the nature of science in a better direction and vice versa, the naive view of students decreases. While the intermediary view can not be seen directly whether it increases or decreases, it depends on its influence on the percentage of the other category (informed and naive).

Table 5 shows the percentage of categorized results of the nature of science that has been categorized into informed, intermediary and naive views, according to the criteria described by Khishfe and Laderman (2006). In general, it can be seen that the categories of science views in both classes do have differences in every aspect, both pretest and posttest. More details, the following will be presented the findings and discussion in the next section.

\subsubsection{Observations and inferences}

The pretest results of the two classes (see Table 5.) show that before the treatment given, over $70 \%$ of the students had a naive view of observation and inferences, with the experimental class superior to the informed view over the control class. So in general, in both classes, the average student is in the naive category, whereas the informed and intermediary categories are few.

The result of the experimental class posttest shows that there is an increasing percentage of students who have informed views on the observation and inferences aspect of $62,5 \%$. This increase was followed by a decrease in the percentage of naive and intermediary, as the percentages switched to informed during posttest. While the result of posttest of control class showed that there was also an increase of percentage of students with informed views about the observation and inferences aspect although smaller compared to the experimental class, that is as much as $45,8 \%$.

\subsubsection{Tentativeness}

Science is tentative, there is not any exact theory and law of science because nature is always changing (Buxer, 2014). Many of the students did not know that science, especially physics is developing. Science tentativeness describes that science is never absolute or certain although it is reliable and durable. Furthermore, science tentativeness is also subject to change shows that the knowledge is based on the result of new evidence and innovation. Hence, the previous theories and laws can be changed.

The pre-test results of the two classes in this aspects shows that before the treatment given, over $60 \%$ of the students had a naive view of science tentativeness, with the experimental class superior to the 8informed view over the control class. So in general, in both classes, the average student is in the naive category, whereas the informed and intermediary categories are few.

The result of the experimental class posttest shows that there is an increasing percentage of students who have informed views on the science tentativeness aspect of $70,8 \%$. This increase was followed by a decrease in the percentage of naive and intermediary, as the percentages switched to informed during posttest. While the result of posttest of control class showed that there was also an increase of percentage of students with informed views about the science tentativeness aspect although smaller compared to the experimental class, that is as much as $45,8 \%$.

Future, the students who get good understanding of science tentativeness expectedly will be able to compete with others globally. Knowledge and technology are the things made up science, as long as there is a new evidence, new cases solved and new observation held. Science and technology will always develop and give human opportunities and innovation.

The atmosphere of the school which research was conducted may affect to the improvement of the students' views or understanding about science tentativeness. Many of the students are interact with new technologies, new reality and new social life in daily, that interaction support 
Table 4. The Students' Score in Each Aspect of NOS

\begin{tabular}{|c|c|c|c|c|c|c|c|}
\hline \multirow[b]{2}{*}{ Class } & \multirow[b]{2}{*}{ Component } & \multicolumn{6}{|c|}{ The Aspect of NOS } \\
\hline & & $\begin{array}{l}\text { observations and } \\
\text { inferences }\end{array}$ & $\begin{array}{c}\text { tentativenes } \\
\mathrm{s}\end{array}$ & $\begin{array}{c}\text { scientific theories } \\
\text { and laws }\end{array}$ & $\begin{array}{c}\text { social and } \\
\text { cultural } \\
\text { embededdness }\end{array}$ & $\begin{array}{l}\text { creativity and } \\
\text { imagination }\end{array}$ & $\begin{array}{l}\text { scientific } \\
\text { methods }\end{array}$ \\
\hline \multirow{5}{*}{ 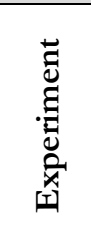 } & Pretest & $-1,67$ & $-2,54$ & $-3,38$ & $-2,79$ & $-2,29$ & $-2,79$ \\
\hline & Posttest & 3,71 & 3,75 & 3,67 & 3,54 & 3,75 & 3,75 \\
\hline & Gain & 5,38 & 6,29 & 7,04 & 6,33 & 6,04 & 6,54 \\
\hline & $\begin{array}{l}\text { Normalized } \\
\text { Gain }\end{array}$ & 0,55 & 0,58 & 0,61 & 0,57 & 0,58 & 0,60 \\
\hline & Category & Medium & Medium & High & Medium & Medium & High \\
\hline \multirow{5}{*}{\begin{tabular}{l}
$\overline{0}$ \\
\multirow{0}{0}{} \\
$\dot{U}$
\end{tabular}} & Pretest & $-2,33$ & $-2,62$ & $-2,95$ & $-2,67$ & $-2,38$ & -3 \\
\hline & Posttest & 1,952 & 2,143 & 2,286 & 2,095 & 1,857 & 2,429 \\
\hline & Gain & 4,286 & 4,762 & 5,238 & 4,81 & 4,19 & 5,429 \\
\hline & $\begin{array}{c}\text { Normalized } \\
\text { Gain }\end{array}$ & 0,377 & 0,433 & 0,449 & 0,429 & 0,363 & 0,467 \\
\hline & Category & Medium & Medium & Medium & Medium & Medium & Medium \\
\hline
\end{tabular}

their new understanding and make them more aware and got the better score in this aspects of nature of science (NOS).

\subsubsection{Scientific theories and laws}

It is proven due to the result of the research that this aspect is the least students are categorized as the informed views where there is less than quarter of the students or participants $(0 \%)$ of the students are categorized as informed views and the control class superior to the experiment class $(4,2 \%)$. In this aspect the pretest results from both classes (see Table 5.) shows that before the treatment, all of students had a naive view of scientific theories and laws, with both classes having no informed views at all. So in general, in both classes, almost all students are in the naive category, whereas the informed category is absent and the intermediary is small.
The result of the experimental class posttest shows that there is high increasing percentage of students who have informed views on the scientific method aspect as much as $79.2 \%$ or $15 \%$ superior if compared with the control class. This increase was followed by a decrease in the percentage of naive and intermediary, as the percentages switched to informed during posttest. While the result of posttest of control class showed that there was also an increase of percentage of students with informed views about scientific theories and laws aspect although smaller compared to experiment class, that is $54,2 \%$.

\subsubsection{Social and cultural embededdness}

The aspects of Nature of Science (NOS) relates to some feature in human life which are the cultural, social, political, ethical, commercial, cognitive, structural and phsylogical (Mattehews, 2012). In the result of the pretest, in this

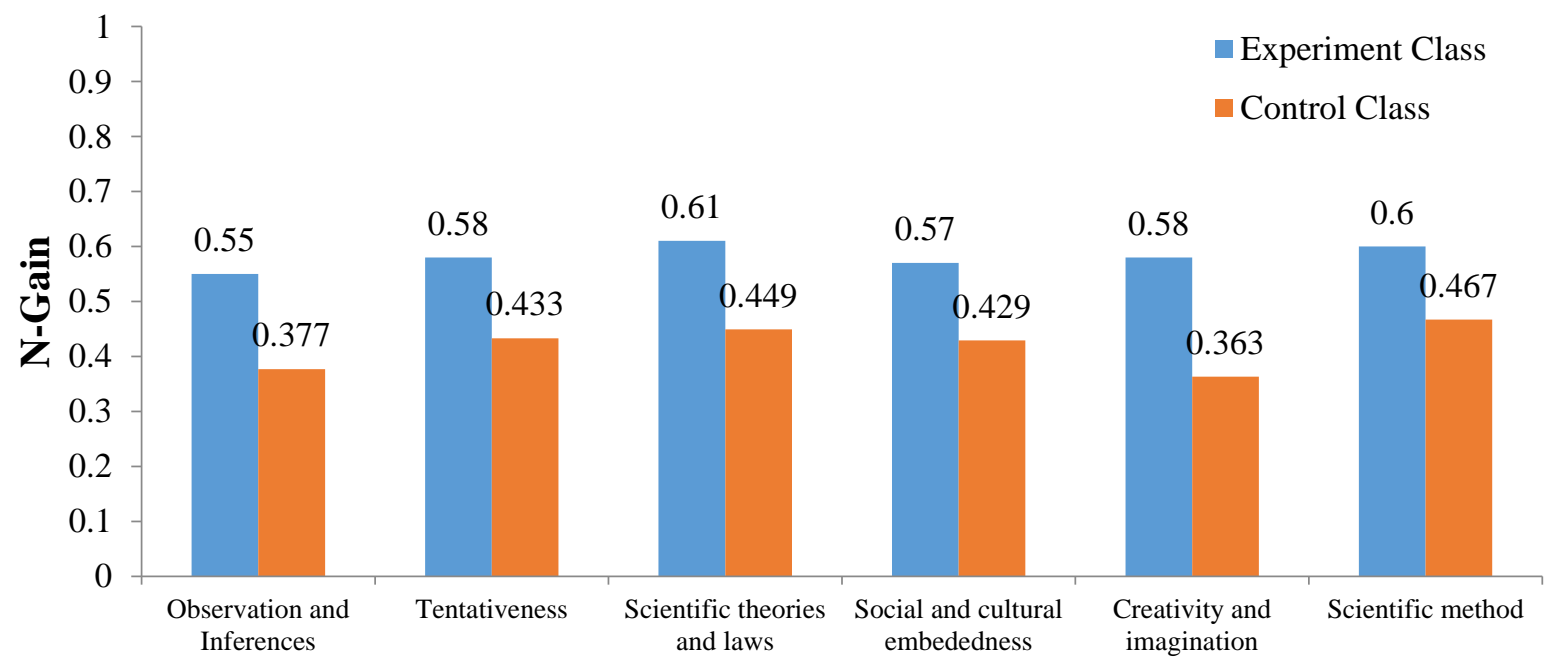

NOS Aspects

Figure $2 \mathrm{~N}$-gain in each aspects of nos between experiment and control class 
Table 5.The categorization result of students' understanding about nature of science (NOS)

\begin{tabular}{|c|c|c|c|c|c|c|c|}
\hline \multirow[b]{2}{*}{ Test } & \multirow[b]{2}{*}{ Aspects } & \multicolumn{3}{|c|}{ Experiment Class } & \multicolumn{3}{|c|}{ Control Class } \\
\hline & & $\begin{array}{c}\text { Naïve } \\
\text { Views (\%) }\end{array}$ & $\begin{array}{l}\text { Intermediary } \\
\text { Views (\%) }\end{array}$ & $\begin{array}{c}\text { Informed } \\
\text { Views } \\
(\%)\end{array}$ & $\begin{array}{c}\text { Naïve } \\
\text { Views } \\
(\%)\end{array}$ & $\begin{array}{c}\text { Intermediary } \\
\text { Views (\%) }\end{array}$ & $\begin{array}{l}\text { Informed } \\
\text { Views (\%) }\end{array}$ \\
\hline \multirow{6}{*}{ 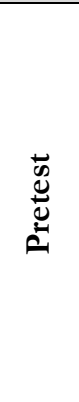 } & $\begin{array}{l}\text { Observations and } \\
\text { Inferences }\end{array}$ & 75 & 16,7 & 8,3 & 79,2 & 16,6 & 4,2 \\
\hline & Tentativeness & 66,7 & 29,1 & 4,2 & 66,7 & 33,3 & 0 \\
\hline & $\begin{array}{l}\text { Scientific theories and } \\
\text { laws }\end{array}$ & 95,8 & 4,2 & 0 & 87,5 & 8,3 & 4,2 \\
\hline & $\begin{array}{l}\text { Social and cultural } \\
\text { embededness }\end{array}$ & 87,5 & 12,5 & 0 & 91,6 & 8,4 & 0 \\
\hline & $\begin{array}{l}\text { Creativity and } \\
\text { imagination }\end{array}$ & 70,8 & 25 & 4,2 & 58,3 & 33,4 & 8,3 \\
\hline & Scientific method & 83,3 & 16,7 & 0 & 75 & 25 & 0 \\
\hline \multirow{6}{*}{$\begin{array}{l}\stackrel{0}{0} \\
\stackrel{ \pm}{\infty} \\
0 \\
0\end{array}$} & $\begin{array}{l}\text { Observations and } \\
\text { Inferences }\end{array}$ & 16,7 & 12,5 & 70,8 & 29,2 & 20,8 & 50 \\
\hline & Tentativeness & 4,16 & 25 & 70,8 & 16,7 & 37,5 & 45,8 \\
\hline & $\begin{array}{l}\text { Scientific theories and } \\
\text { laws }\end{array}$ & 12,5 & 8,3 & 79,2 & 25 & 20,8 & 54,2 \\
\hline & $\begin{array}{l}\text { Social and cultural } \\
\text { embededness }\end{array}$ & 12,5 & 4,16 & 83,3 & 33,3 & 16,7 & 50 \\
\hline & $\begin{array}{l}\text { Creativity and } \\
\text { imagination }\end{array}$ & 8,3 & 8,3 & 83,4 & 29,2 & 16,7 & 54,1 \\
\hline & Scientific method & 4,16 & 16,7 & 79,1 & 25 & 8,3 & 66,7 \\
\hline
\end{tabular}

aspect all the students are categorized also categorized as naive views where there is none of the students or participants $(0 \%)$ of the students are categorized as informed views. In this aspect the pretest results from both classes (see Table 4) shows that before the treatment, all of students had a naive view of scientific theories and laws, with both classes having no informed views at all. So in general, in both classes, almost all students are in the naive category, whereas the informed category is absent and the intermediary is small.

The result of the experimental class posttest shows that there is a high increasing percentage of students who have informed views on the social and cultural embededdness aspect as much as $83,3 \%$ or $33,3 \%$ superior if compared with the control class. This increase was followed by a decrease in the percentage of naive and intermediary, as the percentages switched to informed during posttest. While the result of posttest of control class showed that there was also an increase of percentage of students with informed views about scientific theories and laws aspect although smaller compared to experiment class that is $50 \%$.

\subsubsection{Creativity and imagination}

Creativity and imagination is source of inspiration in science which is used along with logic and prior knowledge (Liang et al., 2008). Science involves the invention of theoritical and explanation requires a great deal of creativity. Hence, creativity and science cannot be apart because it is involved in all stages of scientific investigation and particularly relevant to generate and interpret the data starting from the beginning, during and following the collection of data (Lederman et al., 2012; Chen, 2006; AbdEl-Khalick, 2012).

Creative and imagination support science becomes unique and innovative. A good scientist must be creative in designing a good experiment and also shall be imaginative in coming up with a theory, but shall use scientific method to stay objective (Akerson and Hanuscin, 2007).

Coming up to the result of this research that creativity and imagination aspects. The experimental class posttest shows that there is a high increasing percentage of students who have informed views on creativity and imagination aspect as much as $79 \%$ or $29,3 \%$ superior if compared with the control class. This increase was followed by a decrease in the percentage of naive and intermediary, as the percentages switched to informed during posttest. While the result of posttest of control class showed that there was also an increase of percentage of students with informed views about scientific theories and laws aspect although smaller compared to experiment class, that is $45,8 \%$.

\subsubsection{Scientific methods}

The pretest results from both classes (see Table 5.) show that prior to treatment, over $70 \%$ of students had a naive view of Scientific method, with both classes having no informed views at all. So in general, in both classes, almost all students are in the naive category, whereas the informed category is absent and the intermediary is small. 
The result of the experimental class posttest shows that there is an increasing percentage of students who have informed views on the scientific method aspect as much as $79.1 \%$ or $12.4 \%$ superior when compared with the control class. This increase was followed by a decrease in the percentage of naive and intermediary, as the percentages switched to informed during post-test. While the result of posttest of control class showed that there was also an increase of percentage of students with informed views about the observation and inferences aspect although smaller compared to experiment class, that is $66,7 \%$.

\section{CONCLUSION}

Be rooted in data analysis, the inquiry based laboratory activities appears to have more benefited to the students in terms of understanding about Nature of Science (NOS). The students in the inquiry class scored slightly better than did students in the non-inquiry group, they perceived a statistically significantly bigger gain than did students in the non-inquiry class. So, it can be concluded that the implementation of Inquiry based Laboratory Activity in learning light and optics can improve students' understanding about Nature of Science (NOS).

Based on the findings of the research that has been conducted and concluded, there are several recommendation that necessary to be conveyed by the researcher, some of them are, first before grouping the students in this research, it is important to analyze students' ability. The group members should be consist of high and low achievement students. Teacher also should make sure that each group is working collaboratively. Second, teacher supervision is really necessary in order to make sure that every group member active in giving idea and discussion in their group. While, in the learning process, the students need to be triggered more to formulate the critical questions and relate the laboratory activity with what scientist do in reality. Then, the time allocation to implements the experimental treatment should be considered and determined properly since there are several phases, so the students can finish the laboratory activity optimally.

\section{REFERENCES}

Anderman \& Sinatra. (2008). The Challenges of Teacbing and Learning about Science in the 21st Century: Exploring. Las Vegas: National Academy of Education.
Ausubel, David P. (1969). School learning:an introduction to education psychology. New York: Holt, Rinehart and Winston, Inc.

Azer, S.A., Hasanato,R., Al-Nassar,S., Somily, A.,\&AlSaadi, MuslimM. (2013). Introducing integrated laboratory classes in a PBL curriculum: impact on student's learning and satisfaction.BMC Medical Education, 13 (71), 112. BBC News. (2005, June 19). Science dull and hard, pupils say. Retrieved October 17, 2016, from BBC News: http://news.bbc.co.uk/2/hi/uk_news/education.

Brookes Publishing. (2012). 5 tips for getting all your students engaged in learning. Retrieved October 18, 2016, from: http://archive.brookespublishing.com/articles/ed-article0212.htm

Bunning, Frank. (2013). Effects of experimental learning outcomes of an empirical study in the vocational field of structural engineering. International Journal of Training Research, 11 (1), 44-55.

Cresswel, John W. (2012). Educational research: planning, conducting, and evaluating quantitative and qualitative research. Unated States of America. Pearson.

Fraenkel, J. R., Wallen, Norman E., \& Hyun Helen H. (2007). How to Design and Evaluate Research in Education. New York: McGraw-Hill, Inc.

Hofstein, A. and Lunneta V.N. (2004). The laboratory in science education: Foundations For the twenty-first century. Science Education. 88. 28-54.

Kementerian Pendidikan dan Kebudayaan. (2015). Kurikulum 2013 Kompetensi Dasar. Jakarta: Kemdikbud.

Liang, L., Chen, S., Chen, X., Kaya, O.N., Adams, A.D., Macklin, M., and Ebenezer, J. (2008). Assessing preservice elementary teachers' views on the nature of nature of scientific knowledge. Asia-Pacific Forum on Science Learning and Teaching. 9, 1.

OECD Data. (2015). Science Performance PISA. Retrieved December 12, 2016, from OECD Data:https://data.oecd.org/pisa/scienceperformance-pisa.htm

Olubu, Odutuyi Musili (2015). Effects of Laboratory Learning Environment on Students' Learning Outcomes in Secondary School Chemistry. International Journal of Arts \& Sciences, 8 (2), 507525.

Ozgelen, S., Tuzun, O.Y.,andHanuscin, D.L. (2012). Exploring the Development of Preservice Science Teachers' Views on the Nature of Science in Inquiry-Based Laboratory Instruction. Science and Business Media Dordrecht. 43, 1551-1570.

Tural, G. (2015). Cross-Grade Comparison of Students' Conceptual Understanding with Lenses in Geometric Optics. Science Education International Journal, $26 \quad$ (3), 325-346.

Wang, Jing-Ru., Wang, Yuh-Chao., Tai, Hsin-Jung. \& Chen, Wen-Ju. (2010). Investigating The Effectiveness of Inquiry-Based Instruction on Students With Different Prior Knowledge and Reading Abilities. International Journal of Science and Mathematics Education. 8, 801-820.

Wolf, S.J.,\& Fraser, B.J. (2007). Learning Environment, Attitudes and Achievement among Middle-school Science Students Using Inquiry-based Laboratory Activities. Springer Science + Business Media B.V. 38, 321-341. 
